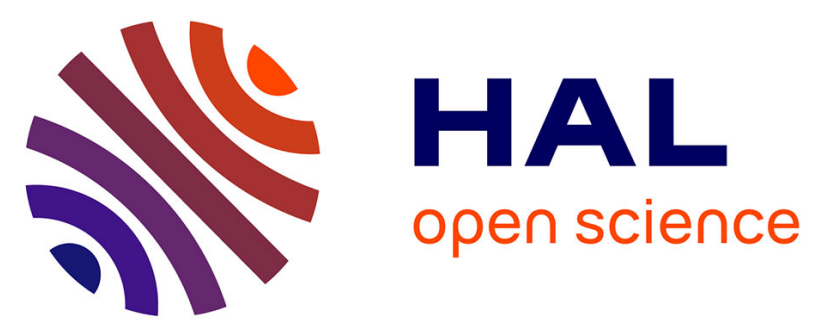

\title{
Envisioning upland futures: Stakeholder responses to scenarios for Europe's mountain landscapes
}

Reto Soliva, Katrina Rønningen, Ioanna Bella, Peter Bezak, Tamsin Cooper, Bjørn Egil Flø, Pascal Marty, Clive Potter

\section{- To cite this version:}

Reto Soliva, Katrina Rønningen, Ioanna Bella, Peter Bezak, Tamsin Cooper, et al.. Envisioning upland futures: Stakeholder responses to scenarios for Europe's mountain landscapes. Journal of Rural Studies, 2008, 24 (1), pp. 56-71. 10.1016/j.jrurstud.2007.04.001 . halshs-01227527

\section{HAL Id: halshs-01227527 https://shs.hal.science/halshs-01227527}

Submitted on 4 Jan 2021

HAL is a multi-disciplinary open access archive for the deposit and dissemination of scientific research documents, whether they are published or not. The documents may come from teaching and research institutions in France or abroad, or from public or private research centers.
L'archive ouverte pluridisciplinaire HAL, est destinée au dépôt et à la diffusion de documents scientifiques de niveau recherche, publiés ou non, émanant des établissements d'enseignement et de recherche français ou étrangers, des laboratoires publics ou privés. 
Soliva R., Rønningen K., Bella I., Bezak P., Cooper T., Egil Flø B., Marty P., Potter C., 2008.

Envisioning upland futures: stakeholder responses to scenarios for Europe's mountain landscapes.

Journal of Rural Studies: 24(1): 56-71 


\title{
Envisioning upland futures: Stakeholder responses to scenarios for Europe's mountain landscapes
}

\author{
Reto Soliva $^{\mathrm{a}, *}$, Katrina Rønningen ${ }^{\mathrm{b}}$, Ioanna Bella ${ }^{\mathrm{c}}$, Peter Bezak ${ }^{\mathrm{d}}$, Tamsin Cooper ${ }^{\mathrm{e}}$, \\ Bjørn Egil Flø $\varnothing^{\mathrm{b}}$, Pascal Marty ${ }^{\mathrm{f}}$, Clive Potter ${ }^{\mathrm{e}}$ \\ ${ }^{a}$ Swiss Federal Research Institute WSL, Zürcherstrasse 111, 8903 Birmensdorf, Switzerland \\ ${ }^{\mathrm{b}}$ Centre for Rural Research, University Centre, 7491 Trondheim, Norway \\ ${ }^{\mathrm{c}}$ Department of Economics, University of Macedonia, 156 Egnatia Street, 54006 Thessaloniki, Greece \\ ${ }^{\mathrm{d}}$ Institute of Landscape Ecology of the Slovak Academy of Sciences Bratislava, Branch Nitra, Akademická 2, 94901 Nitra, Slovak Republic \\ ${ }^{\mathrm{e}}$ Centre for Environmental Policy, Imperial College London, Prince Consort Road, London SW3 2AZ, UK \\ ${ }^{\mathrm{f}}$ Centre d'Ecologie Fonctionnelle et Evolutive, CEFE, UMR 5145 CNRS, 1919 Route de Mende, F 34293 Cedex 5, Montpellier, France
}

\begin{abstract}
In a period of agricultural decline in the uplands of Europe, agriculture is ceasing to provide the primary rationale for the organisation, utilisation and functioning of rural space. Policy reform, market trends and changes to the way citizens and consumers think about the countryside all suggest a need for thinking strategically about the future development of these areas. However, without a broad involvement of stakeholders, land use conflicts, and social and cultural conflicts in general, may increase. Involving stakeholders in upland areas can be facilitated by using scenario technique and by discussing alternative futures in local stakeholder panels. In this paper we present four scenarios of land-use change for the year 2030, and their assessments by stakeholder panels in Scotland, France, Norway, Switzerland, Slovakia and Greece. The aim of the paper is to explore the ways in which stakeholders in these locations advocate and assess these scenarios. We also explore how stakeholders in different countries weight the visual landscape impacts, the livelihood and biodiversity aspects of the scenarios in their assessment, and the reasons for their prioritising. The cross-country analysis shows that stakeholders across the study areas are united in their overall rejection of agricultural liberalisation, advocating a production-oriented, but multifunctional and environmentally-friendly agriculture that maintains landscapes and biodiversity.
\end{abstract}

(C) 2007 Elsevier Ltd. All rights reserved.

Keywords: Agricultural decline; Scenarios; Landscape; Biodiversity; Stakeholders; Mountains; BioScene; Europe

\section{Introduction}

Europe's mountain areas are complicated places. Important reserves of biodiversity and natural beauty, they are also the home to several million people. The linking factor here is agriculture, low intensive farming systems giving rise to the extensive areas of semi-natural and cultural landscapes of great diversity, due to the natural, socio-economic and cultural variations throughout Europe.

Many of these landscapes now stand on the threshold of major change. Significant restructuring of the agricultural,

\footnotetext{
${ }^{*}$ Corresponding author. Tel.: + 41447392353 ; fax: +41447392588

E-mail address: reto.soliva@wsl.ch (R. Soliva).
}

social and economic fabric of mountain areas has been occurring for decades, but we are now arguably at a juncture where new accelerated processes of agricultural decline could have dramatic consequences for livelihoods and biodiversity. In one sense, upland agriculture is in the process of reinventing itself as a guardian of the landscape and provider of public goods. Current trends in consumer behaviour and food markets such as slow food, niche production, organic food, local food and alternative agrofood networks (e.g. Marsden et al., 1999; van der Ploeg and Renting, 2000; Miele and Murdoch, 2003; Goodman, 2004; van der Ploeg and Renting, 2004; Tellstrom et al., 2005) are creating new markets for mountain farm products that cannot compete within the conventional food sector due to higher production costs. Moreover, the 'greening' of 
agriculture through agri-environmental schemes is likely to benefit mountain areas, as such schemes traditionally have favoured less intensively farmed areas (Rønningen, 1999). The full potential and economic implications of these trends for European uplands are uncertain, however, and may vary significantly between different regions in Europe. At the same time, international pressures to retrench agricultural support and liberalise agricultural markets look likely to intensify the cost-price squeeze on farm family income, leading to an acceleration in the rate of outflow from upland agriculture. Some see agricultural decline offering an opening for conservation. While many of the ecologically valuable habitats and species in European uplands to a large extent depend on human impact mainly through low intensive farming systems with grazing and fodder harvesting (Jodha, 1997; Parish, 2002; Bätzing, 2003; Dodgshon and Olsson, 2007), mountain areas in many European countries are also where the protection of natural processes and species with large territorial requirements (such as large carnivores) is most feasible. Thus, different-and only partly compatibleconservation interests meet in mountain areas.

Policymakers and those who advise or seek to influence them will increasingly be confronted with the question how far, and in what way, should these processes of decline and restructuring be managed in the public interest? Are the agriculturally managed landscapes of Europe's uplands sufficiently important to justify continued high levels of government support for the farming sector and for rural development there? Can other futures now be contemplated involving a different configuration of human activity and natural processes? While rarely posed in public debate, such questions are becoming increasingly relevant to the long term framing of public policy. Dealing with these questions involves a high degree of uncertainty. Scenarios provide an approach to help manage the inherent uncertainties of decisions based on assumptions, rather than on facts, by examining several alternatives of how the future might unfold and comparing the potential consequences of different future contexts (Shearer, 2005). They can integrate different aspects of alternative futures for mountain areas, such as landscape appearance, livelihoods and biodiversity.

'Local participation', 'bottom-up-planning', 'participatory planning', 'including stakeholders' and 'local empowerment' have become catch words within conservation and development projects (see Twyman, 2000; Cooke and Kothari, 2002; Daugstad et al., 2006a; Svarstad et al., 2006). The last decade has seen a large number of locally implemented projects concerning sustainable development, biological conservation and democratisation. The necessity to include local people and other stakeholders to achieve just and sustainable solutions, and to utilise local knowledge (CBD, 1992; Fraser et al., 2006) is generally acknowledged. Scientific research that takes into account the views of local stakeholders has the potential to give a voice to those who are directly affected by political and adminis- trative decisions, and whose daily actions shape and maintain mountain areas. Discussing scenarios with local stakeholders is thus a promising way to contribute to integrative and broadly accepted planning and policies.

In recent years, European landscape research has focused on applied landscape studies taking into account people's perceptions and images, as well as the participation of the public and stakeholders (Buijs et al., 2006; Pedroli et al., 2006). There are several studies dealing with ongoing landscape changes as a consequence of changes in agricultural policy (e.g. Søderkvist Kristensen et al., 2004; Pinto-Correia et al., 2006). Numerous studies have developed scenarios for future agricultural landscapes, often involving GIS-based modelling (e.g. Höll et al., 2002; Münier et al., 2004; Ewert et al., 2005 and in the recent EURURALIS and ATEAM projects: Rounsvell et al., 2006; van Meijl et al., 2006; Verburg et al., 2006; Westhoek et al., 2006; for a review of recent quantitative land use scenario studies in Western Europe see Busch, 2006). There is, however, relatively little empirical research which investigates the ways in which stakeholders assess landscape scenarios and alternative futures for rural areas. Recent examples include Palang et al. (2000) in Estonia, Scholz et al. (2002) in Switzerland and Tress and Tress (2003a, b) in Denmark. For an example of participatory scenario building, see Barbanente et al. (2002). To date, studies involving stakeholder assessments of scenarios that explicitly deal with European mountain areas are lacking, as are cross-country comparative studies of scenarioassessments by stakeholders. This paper aims to address this research gap. It describes some outcomes of the EU 5th Framework research project BioScene-Scenarios for reconciling biodiversity conservation with declining agricultural use in the mountains of Europe - in which stakeholder panels in six European countries-Slovakia, Greece, France, Switzerland, Scotland and Norway - were convened to assess a number of scenarios for mountain communities and landscapes for the year 2030. The main objective of the paper is to explore similarities and differences in the ways in which local stakeholders across European uplands advocate and assess different future scenarios, and the priorities, values and preferences which these discussions have revealed. How do stakeholders in different countries weigh the visual landscape impacts, the livelihood and biodiversity aspects of the scenarios in their assessment, and what may be the reasons for the different priorities they express?

\section{Methodology and approach}

\subsection{The study areas: an overview}

Six study areas of mountain communities were selected: The Cairngorms in Northeast Scotland, the Causse Méjan in Southern France, Eastern Jotunheimen in South-Central Norway, the Surses valley in Southeast Switzerland, Zagori in Northwest Greece, and Poloniny National Park in 


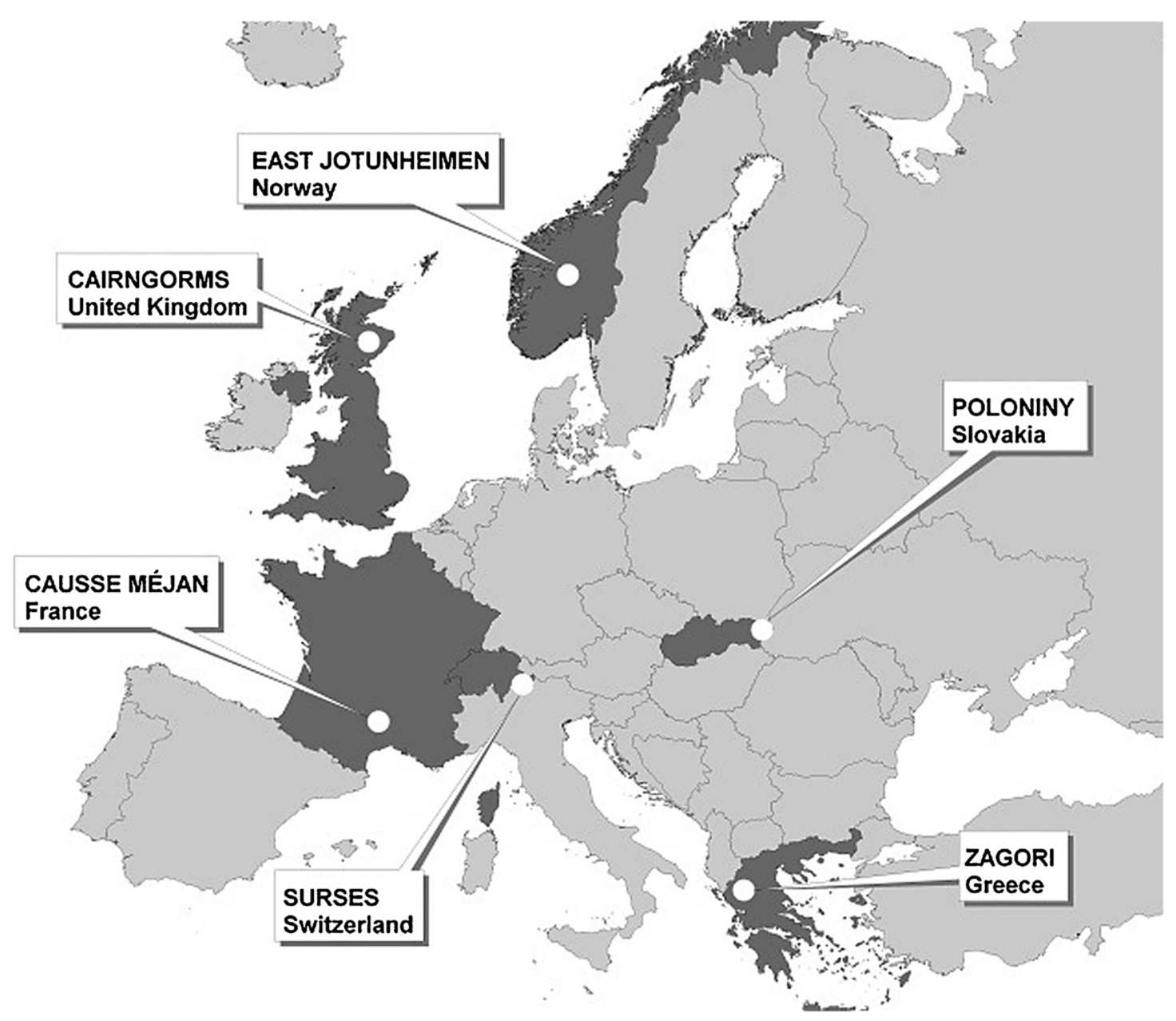

Fig. 1. Location of the six BioScene study areas (map by P. Bezák).

Eastern Slovakia. These represent mountain areas from different biogeographical regions; they vary in size and population and are quite diverse with regard to their socioeconomic situation and agricultural systems. In most study areas, agricultural production has been recorded for hundreds or even thousands of years. The long history of human use has led to the development of species-rich, specialised and relatively stable biological communities (see, for instance Marty, 2005 about the French study area, and Olsson et al., 2004, about the Norwegian study area). The protected areas (national and regional parks) that exist in all study areas testify to the landscape and biodiversity values of these areas. However, over the last decades the utilised agricultural area has been declining in all study areas, and forest cover has increased. Fig. 1 shows the locations of the study areas in Europe.

Most upland areas in Europe have undergone dramatic changes in the post-war period; in some areas (like in the Eastern European states after the end of the socialist era), these changes have been abrupt, whereas in others, they have been more gradual. While some mountain areas have already transformed considerably, having developed mass tourism, 'soft' eco-tourism, niche food strategies, or because they are attractive for re-ruralisation by new types of incomers, other more marginal areas are facing a very uncertain future in view of further agricultural liberalisation. Finally, the extent of agricultural decline, land abandonment and subsequent natural reforestation differs between the study areas, which contributes to variations in stakeholders' assessment of the socio-economic, cultural, visual/aesthetic and environmental consequences of these processes. Table 1 gives an overview of some features of the different study areas.

\subsection{Stakeholder participation}

Semi-structured interviews with local stakeholders in each study area were carried out as a first step, focusing on people's perceptions of landscape and biodiversity changes due to agricultural decline in the last 25 years, and their expectations and wishes regarding the landscape in the year 2030. From those interviewed, up to 12 were recruited as members of the Stakeholder Panels. These included people with different personal and professional backgrounds; farmers, other land owners and land managers, representatives of conservation organisations and protected areas, representatives of tourism-related businesses and field sports associations, local residents and owners of holiday 
Table 1

Study areas of the BioScene project

\begin{tabular}{|c|c|c|c|c|c|c|c|c|c|c|}
\hline Study area & $\begin{array}{l}\text { Size of } \\
\text { study area } \\
\text { (ha) }\end{array}$ & $\begin{array}{l}\text { Elevation } \\
\text { range (m } \\
\text { a.s.l.) }\end{array}$ & Population & $\begin{array}{l}\text { Population } \\
\text { predominantly } \\
\text { engaged in } \\
\text { agriculture }\end{array}$ & Land-use & $\begin{array}{l}\text { Farm } \\
\text { number }\end{array}$ & $\begin{array}{l}\text { Median } \\
\text { size of } \\
\text { farms }\end{array}$ & $\begin{array}{l}\text { Agricult. } \\
\text { land (ha) }\end{array}$ & $\begin{array}{l}\text { Agricultural } \\
\text { production }\end{array}$ & Special remarks \\
\hline $\begin{array}{l}\text { Greece: } \\
\text { Zagori }\end{array}$ & 15,600 & $630-2490$ & 1079 & n.a. & $\begin{array}{l}40 \% \text { forest, } 2.7 \% \\
\text { farmland, } 33.4 \% \\
\text { communal or municipal } \\
\text { land }\end{array}$ & 384 & n.a. & 1079 & $\begin{array}{l}\text { Sheep and goats, } \\
\text { fodder } \\
\text { production }\end{array}$ & $\begin{array}{l}\text { Increasingly popular } \\
\text { with tourists and } \\
\text { incomers from urban } \\
\text { areas }\end{array}$ \\
\hline $\begin{array}{l}\text { Slovakia: } \\
\text { Poloniny NP }\end{array}$ & 34,191 & $240-1221$ & 2957 & $\begin{array}{l}30-35 \% \\
\text { (estimation) }\end{array}$ & $\begin{array}{l}85 \% \text { forest, } 13 \% \\
\text { agricultural land (out of } \\
\text { which } 26 \% \text { intensive, } \\
58 \% \text { extensive meadows, } \\
16 \% \text { meadows/fields } \\
\text { mosaic) }\end{array}$ & 2 & 4000 ha & 4300 & $\begin{array}{l}\text { Beef and cattle, } \\
\text { forage }\end{array}$ & $\begin{array}{l}\text { Resettlement of seven } \\
\text { villages before the } \\
\text { construction of a } \\
\text { barrage in the } 1970 \text { s. } \\
\text { Two formerly state- } \\
\text { run land-management } \\
\text { units (forestry and } \\
\text { agriculture) manage } \\
\text { most of the productive } \\
\text { land in the area. }\end{array}$ \\
\hline $\begin{array}{l}\text { France: } \\
\text { Causse Méjan }\end{array}$ & 35,000 & $800-1247$ & 480 & n.a. & $\begin{array}{l}39 \% \text { forest, } 11 \% \text { crop } \\
\text { land, } 50 \% \text { grassland }\end{array}$ & 54 & 300 ha & 25,400 & $\begin{array}{l}\text { Mainly sheep } \\
\text { (lambs and } \\
\text { cheese) }\end{array}$ & $\begin{array}{l}\text { Agriculture is the } \\
\text { main activity, but } \\
\text { rangelands are } \\
\text { increasingly colonised } \\
\text { by pines. }\end{array}$ \\
\hline $\begin{array}{l}\text { Scotland: } \\
\text { Cairngorms }\end{array}$ & 380,000 & $200-1309$ & 17,000 & $11 \%$ & $\begin{array}{l}23 \% \text { forest, } 17 \% \\
\text { farmland, } 48 \% \text { heather } \\
\text { moorland }\end{array}$ & 202 & n.a. & $\begin{array}{l}\text { Approx. } \\
10,000\end{array}$ & $\begin{array}{l}\text { Mainly sheep } \\
\text { breeding }\end{array}$ & $\begin{array}{l}65 \% \text { of the land is in } \\
\text { the hand of } \\
\text { individuals owning } \\
\text { estates of } 400 \text { ha or } \\
\text { more. }\end{array}$ \\
\hline $\begin{array}{l}\text { Switzerland: } \\
\text { Surses }\end{array}$ & 32,400 & $1000-3400$ & 2360 & $\begin{array}{l}7 \% \text { (full time } \\
\text { only); } 22 \% \text { incl. } \\
\text { part time and } \\
\text { forestry }\end{array}$ & $\begin{array}{l}18 \% \text { forests and shrub } \\
\text { land, } 4 \% \text { farmland, } 37 \% \\
\text { summering pastures, } \\
39 \% \text { unproductive area }\end{array}$ & 108 & 17.7 ha & 1906 & $\begin{array}{l}\text { Mainly dairy } \\
\text { and meat cattle; } \\
\text { pastoral } \\
\text { transhumance } \\
\text { system (summer } \\
\text { farms) }\end{array}$ & $\begin{array}{l}\text { Heavy dependency of } \\
\text { the regional economy } \\
\text { on winter tourism }\end{array}$ \\
\hline $\begin{array}{l}\text { Norway: East } \\
\text { Jotunheimen }\end{array}$ & 800,000 & $350-2341$ & 6321 & $17 \%$ & $\begin{array}{l}15 \% \text { forest (partly } \\
\text { unproductive), } 2 \% \\
\text { farmland, } 70 \% \\
\text { alpine-subalpine with } \\
\text { mainly barren land, } \\
\text { shrubs, some summering } \\
\text { pastures }\end{array}$ & 390 & 16 & 6321 & $\begin{array}{l}\text { Mainly dairy } \\
\text { and sheep; } \\
\text { pastoral } \\
\text { transhumance } \\
\text { system (summer } \\
\text { farms) }\end{array}$ & $\begin{array}{l}\text { Small-scale farming } \\
\text { structure; grazing in } \\
\text { the mountains and } \\
\text { 'outfields' crucial part } \\
\text { of the farming system; } \\
\text { important biodiversity } \\
\text { and landscape values } \\
\text { connected to } \\
\text { mountain summer } \\
\text { farms. }\end{array}$ \\
\hline
\end{tabular}


homes in the areas, and representatives from the local or regional administration, representing as broad a range of views and ideas as possible. Three group discussions were conducted with the Stakeholder Panels in each study area in 2003 and 2004. In the first meeting, the topics of the semi-structured interviews were discussed in more depth in a group setting, and narratives of landscape change were explored (Soliva, 2007). In the second meeting, the scenarios (which will be presented below) were discussed and assessed by the stakeholders, and in the third meeting, sustainability issues were discussed. The meetings were all tape-recorded, transcribed and analysed using qualitative content analysis. In this paper, we draw mostly on the transcripts of the second stakeholder meeting, and on the associated questionnaires filled out by stakeholders (see below).

The composition of the stakeholder panels was fairly similar in the different countries. Participants in stakeholder panels often tend to be relatively resourceful, and some of them may be regarded as 'rural winners' in relation to the processes of rural restructuring which this project seeks to examine. Some panels had stronger representation of outspoken environmentalists or conservationists than others. Most participants in the panels were mid-aged, with only few participants under 30 or above 60 years. There was also a certain male dominance in the panels. However, altogether there was a good cross-section of professional, economic, as well as sectional interests represented in the stakeholder groups.

\subsection{Designing scenarios for the year 2030}

Scenarios are a widely-used tool, employed by researchers, government agencies and policy-makers because they are seen to facilitate imaginative thinking, and to encourage people to step outside of conventional ways of understanding an issue (Shearer, 2005). They may be used as a strategic planning tool to afford a better basis for decision making or as a wider approach to facilitate a discussion about ongoing restructuring and its consequences. The BioScene study used scenario analysis as a research tool for assessing the evolution of mountain landscapes under contrasting policy and socio-economic drivers. Four scenarios of agricultural and conservation policy developments were developed for the year 2030: a Business as Usual scenario, an Agricultural Liberalisation scenario, a Managed Change for Biodiversity scenario, and in three of the countries, a Wilding scenario. The year 2030 was selected as a target date in order to define a "medium term' time horizon which is sufficiently short term that climate change effects would not need to be explored yet sufficiently long term that it allows enough time for some ecological and landscape changes to become visible, while it is still in the life span of most stakeholders and relevant for current long-term policy decisions. A challenge was to make the scenarios study-area specific and at the same time as comparable as possible between the study areas. In general, priority was given to constructing scenarios that make sense for each study area, rather than trying to achieve perfect comparability. Comparisons and comparative studies, especially between countries, will always have a number of methodological difficulties. Some of the differences in the assessments relate to what assumptions underpin the scenarios in different national and local contexts.

With the exception of the Business as Usual scenario, the scenarios developed can be regarded as 'extreme'. Scenarios are understood as 'imaginative pictures of potential futures' (Penker and Wytrzens, 2005) rather than prognoses, forecasts, or predictions. They deal with the question 'what might happen, if...', and do not predict what will happen in the future (Veeneklaas and van den Berg, 1995). Thus, none of the scenarios illustrates the most realistic situation in the year 2030; reality will probably lie somewhere between the scenarios. The characterisation of the scenarios by the researchers has exclusively been based on qualitative reasoning and can be seen as a thought experiment in which the researchers tried to imagine what the future in the study areas might look like-regarding landscape, livelihoods and biodiversity - if certain developments were to take place over the next 25 years. Drawing on information about the agricultural structure of the study areas and study-area specific literature, reflecting recent trends and possible future developments in agricultural and conservation policies, the main agricultural and conservation policy drivers were identified. Assumptions about how these drivers would vary under each scenario were then made, and coherent and interdependent causal chains were constructed, leading from national and international policy and economic drivers to concrete land use consequences in the study areas. Ecological modelling was used to determine the probable effects of the scenarios on priority habitats and species (Halabuk and Halada, 2006; Haddock et al., 2007; Bolliger et al., in press; Caplat et al., submitted; Olsson et al., submitted). Finally, the likely land use and landscape consequences of the scenarios were visualised using photo simulations and presented to the stakeholders. Scenarios can be visualised in a number of ways. For our purposes, photorealistic visualisations based on colour land photographs were regarded as the most appropriate technique because they deliver the most 'natural' image of a landscape. Photographs are a very close representation of reality and thus facilitate communication with non-expert stakeholders (Al-Kodmany, 1999; Orland et al., 2001). The use of visualisation technique for scenario studies is discussed in detail by Tress and Tress $(2003 \mathrm{a}, \mathrm{b})$. The photo editing software used for the visualisations was Adobe Photoshop. Several photo series were produced illustrating possible landscape changes for the scenarios in different settings within the study areas. Settings were selected that represent typical landscape types or typical habitats with a potential for transition under the different scenarios. This was to ensure that the photographs visualised changes at different landscape scales. 
Each of the series consisted of photo manipulations for each scenario with a time frame of 25 years, spanning the period from the present day to 2030 (Figs. 2-4).

The BioScene scenarios were:

Business as Usual (BAU): The Business as Usual (BAU) scenario assumes that the key structural, policy and socioeconomic trends in land-use and agriculture unfurling in
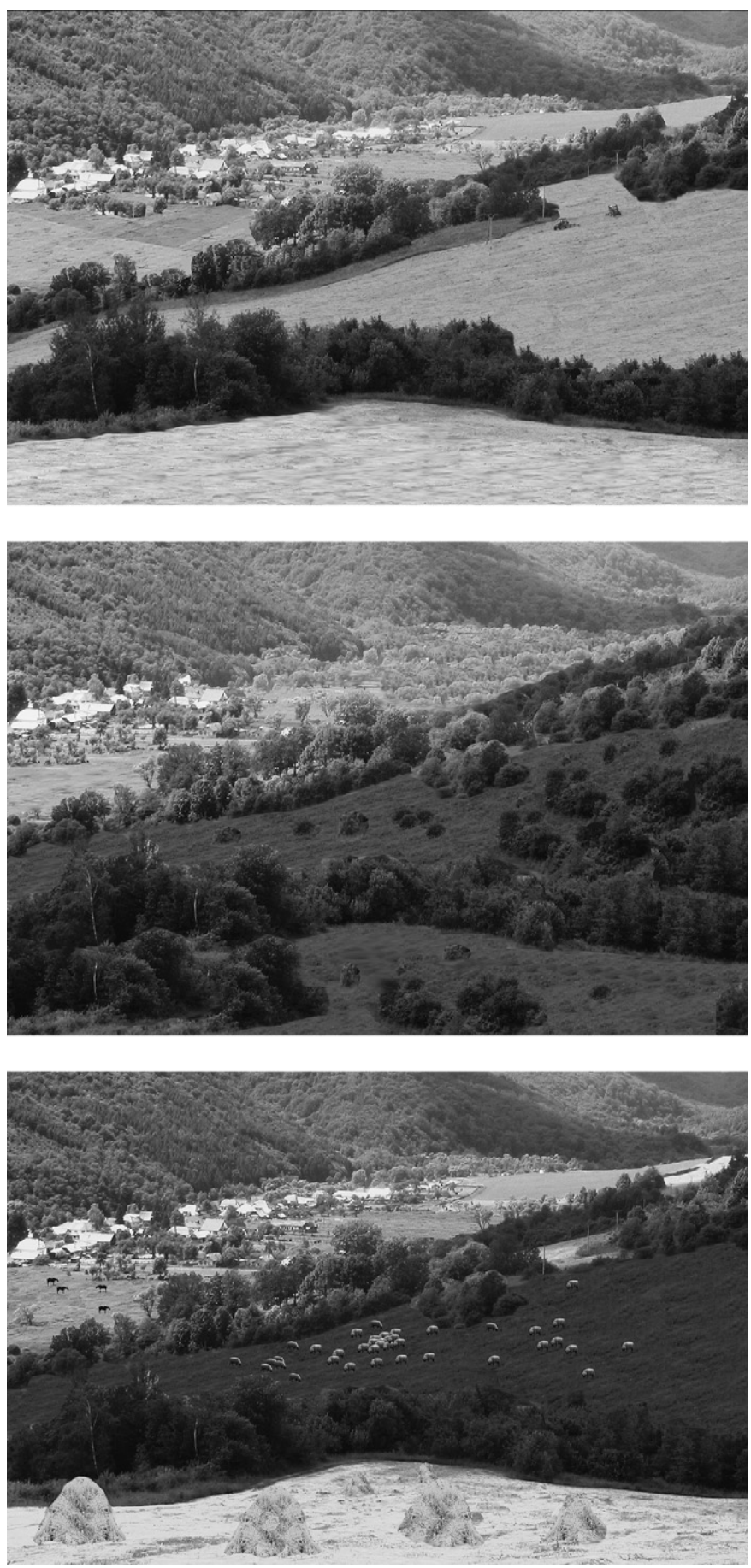

Fig. 2-4. Example of a scenario visualisation series from the Slovakian study area. 2. Business as Usual; 3. Agricultural Liberalisation; 4. Managed Change for Biodiversity (photographs: P. Bezák, photo editing: Martin Boltiziar; note that full colour prints were used for the stakeholder assessments). the study areas will continue into the future. It further assumes that these trends will take place at a similar rate and to a similar extent, with no dramatic changes to the core principles of current policies. While it rests on the proposition that the occupancy of the land by farmers is important to ensuring rural stability and the delivery of certain biodiversity goals over the next 25 years, it also contends that agricultural restructuring will continue along established trajectories, leading to farm amalgamations and the abandonment of marginal land. In terms of biodiversity, the progressive marginalisation of agricultural land is expected to have negative consequences on openland species, but on the other hand, the assumed strengthening of agri-environmental schemes is likely to benefit biodiversity. The magnitude of the biodiversity consequences varies between the study areas.

Agricultural Liberalisation (LIB): A key assumption underpinning the Agricultural Liberalisation scenario is that the complete withdrawal of support to farmers would take place over a short period. Drawing on local knowledge and other research (e.g. studies into farm incomes), we would expect that over the next 25 years there will be a significant exodus from farming in all study areas due to a high dependence on agricultural support. In most countries it is assumed that under the Agricultural Liberalisation scenario a significant portion of agricultural land will be abandoned, and revert to shrubs and eventually to forest. This would be beneficial for forest species, but detrimental to the conservation of open-land species.

Managed Change for Biodiversity (MCB): In contrast to the BAU and LIB scenarios, the Managed Change for Biodiversity scenario is a normative scenario, in that biodiversity conservation is its explicit goal. It is assumed that conventional agricultural support is withdrawn with the monies subsequently reallocated to promote biodiversity conservation in open land habitats in line with a redirection in government policy. Agriculture continues to be an important form of land management under this scenario but it is regarded primarily as a tool of conservation management rather than of production. To a varying degree it is assumed that agri-environmental schemes are tightened in this scenario and that part of the land is managed by conservation organisations, rather than local farmers. Generally, one might expect to see the emergence of a landscape in which biotopes and features are highly structured and interconnected.

Wilding: The Wilding scenario was developed for the French, Scottish and Norwegian study areas. Like the MCB scenario, it is based on the assumption of complete agricultural liberalisation and it also embodies biodiversity conservation as an overarching policy goal. The main difference from MCB is that its conservation objectives are based around more radical biodiversity futures and refer to the conservation and re-establishment of landscape ecological processes rather than species and habitat objectives. Furthermore, large predators may, in some cases, be reintroduced. It represents a "managed re-wilding" approach 
in which obstacles to ecological processes are actively removed. It is expected that conservation organisations will play an important role in the management of land under this scenario.

Stakeholders were asked to assess different dimensions of the scenarios separately: the socio-economic dimension linked to rural livelihoods and cultures, the visual landscape dimension, and the biodiversity dimension. The scenarios were rated by stakeholders on a five point scale, and discussed deliberatively (see Bezák and Petrovic, 2006; Soliva and Hunziker, submitted, for a more detailed presentation of the Slovak and Swiss scenario assessments). ${ }^{1}$

\section{Stakeholders' assessments of the scenarios}

\subsection{Landscape consequences}

There are broad similarities in the visualisation ratings between the study areas: BAU and MCB were mostly rated positively, while LIB and WILDING were rated negatively. The visual landscape impacts of the MCB scenario scored highest in all countries except Greece. Whilst in France and Norway the MCB visualisations were assessed significantly more positively than those of the other scenarios, in the other countries they were assessed in a similar way to the BAU visualisations. This may be due to the fact that the French and Norwegian BAU visualisations indicate a more pronounced trend towards spontaneous reforestation than in the other countries, which was generally associated with agricultural decline and assessed

\footnotetext{
${ }^{1}$ Stakeholders' assessments of the scenarios were carried out in several steps: Firstly, a questionnaire containing the visualisations and-in all countries except Scotland - some text items. The questionnaire was sent to the stakeholders, who were asked to rate the scenarios on a five point Likert scale. At that time, the respondents did not know the scenarios yet, so that the focus of the visualisation rating was on the visual landscape quality. The text items were also decoupled from the scenarios and thematically focused on the main drivers of change (agricultural and conservation policy), on the main processes of change (land abandonment and spontaneous reforestation), and on notions and values related to biodiversity.

In a second step, we invited the stakeholders to a meeting. No specific background information was given to the panellists prior to the meeting. First, the scenarios were presented and deliberatively discussed, focusing on the question what the scenarios would mean for the inhabitants of the study areas. Facilitators had a list of topics to be discussed, but within certain limits the panellists were free to add or dismiss topics. After the discussion they were asked to rate the scenarios in terms of their socioeconomic and cultural consequences. Then, the visualisations were matched to the scenarios and the results of the visualisation rating were presented, followed again by an open discussion.

Finally, the likely biodiversity consequences of the scenarios, as determined in the ecological modelling, were presented to stakeholders, and the scenarios were rated as entities, comprising a visual aesthetic dimension on the landscape level, and a non-visual dimension that includes socio-economic/cultural and biodiversity aspects. Although several of the techniques were semi-quantitative, they are more valuable as qualitative data, and that is how they mainly have been used in this article.
}

negatively by stakeholders. Norwegian stakeholders strongly disliked the visual consequences of forest regrowth: "The birch is like weed", and "the landscape is getting darker and uglier". In the other countries - with the exception of Greece - the BAU visualisations resemble the current situation in which tree encroachment is not yet visually dominant. Stakeholders in all study areas appeared to favour small-structured landscapes resulting from the MCB scenario and disliked the liberalisation and wilding visualisations showing much abandoned land and expanding scrubland and forests.

The assessment of the visual landscape impacts of the scenarios was influenced by other, non-visual aspects. In the French stakeholder meeting, for instance, the discussion about scenic landscape values was typically interwoven with comments on livelihood, on agricultural or pastoral use or on the quality of the natural habitats available in each configuration. Images showing pine colonisation were generally assessed negatively because they were associated with agricultural decline, rather than for purely aesthetic reasons. An aspect highlighted by Norwegian stakeholders was that the strong increase in vegetation cover leads to overgrown paths and loss of viewpoints and scenic qualities, and thus reduced access to and attractiveness of recreational activities in mountain landscapes, both for locals and tourists.

Land abandonment and spontaneous reforestation, resulting from the Liberalisation and Wilding scenarios, are processes that have been discussed in the stakeholder meetings and assessed in the questionnaire. These processes were generally assessed negatively by stakeholders for a number of reasons:

- As processes, land abandonment and spontaneous reforestation were associated with agricultural decline and its negative consequences for livelihoods and rural viability (see below). Many of the specific reasons why land abandonment and spontaneous reforestation were rejected are thus linked to livelihood aspects.

- Land abandonment as an outcome was perceived by most stakeholders as a loss of cultural heritage and tradition. This is particularly true for the Greek and Norwegian study areas, where much of the land is already forested; in the Greek study area, much of the agricultural land has already been abandoned and traditional land uses and practices - e.g. viniculturehave all but disappeared. Most of the stakeholders in these two countries also thought that land abandonment and spontaneous reforestation were disrespectful to the labours of their ancestors.

- Stakeholders in France, Switzerland and-to a lesser extent-Slovakia believed that land abandonment leads to a higher risk of natural hazards such as forest fires (in France), avalanches, mudflows and landslides (in Switzerland) and erosion (in Slovakia). In the other countries, natural hazards were less of an issue. 
In Norway and Switzerland, the majority of stakeholders viewed land abandonment as critical for food supply in times of crisis, as they saw it as an indicator of a loss of selfsufficiency. Some Swiss stakeholders - not only those who had experienced food shortages during WWII themselvessaw memories of WWII as a reason for maintaining agricultural viability. Norwegian stakeholders are more concerned about potential shortages of food supply in certain areas in harsh winters. More important, probably, is that a certain self sufficiency is a part of official policies both in Norway and Switzerland, as both countries are only producing between $50 \%$ and $60 \%$ of their consumed calories themselves (Swiss Federal Council, 2007). Thus, the issue of keeping up a certain national food production is very much alive.

\subsection{Livelihoods and socio-cultural consequences}

The livelihood and socio-cultural consequences of agricultural change emerged as important concerns for stakeholders in all of the study areas. In Slovakia, France, Scotland and Switzerland, stakeholders on average preferred the BAU scenario regarding its livelihoods and cultural consequences. It projects a future that is not very different from the present situation and was thus seen by stakeholders as knowable and safe:

I think the Business as Usual is certainly a safe option, isn't it? (...) And by doing Business as Usual, we know roughly what's going to happen because we know what's been happening in the past 25 years. (Scottish stakeholder)

Even in the BAU scenario, some stakeholders found uncertainty, for instance in Scotland regarding the way the government will chose to implement the latest round of CAP reforms. In Norway, stakeholders were more critical in their assessment of the BAU scenario. They saw the BAU mainly as a slower version of the liberalisation scenario that they would go on to reject as a future for the community. In Slovakia, on the other hand, stakeholders welcomed the BAU scenario because it assumes a continuation of recently established agricultural and development support from the EU. Security and predictability are probably less important features of the BAU scenario, as stakeholders on the Slovak panel have experience with drastic changes within short time periods. Finally in Switzerland, most stakeholders seemed to be quite satisfied with their current livelihoods, which they hope to maintain under a BAU scenario. They welcomed a continuation of agricultural restructuring at the current pace as the only way to ensure the survival of mountain agriculture even if it entails more land abandonment. It should be noted, however, that most of the farmers participating in the Swiss stakeholder panel can be characterised as winners of agricultural restructuring who have been able to expand their farm businesses. Thus it seems that recent personal experiences of agricultural change, and more generally the level of satisfaction with the present situation, influence the way stakeholders assess the BAU scenario.

Stakeholders appear united in their rejection of the livelihood and cultural consequences of the liberalisation and wilding scenarios. Regarded as a 'nightmare scenario' by some stakeholder groups, liberalisation was interpreted as a far-reaching and generally destructive process, going beyond agriculture to affect most aspects of life in rural areas. This was assumed to include a general withdrawal by governments from rural development projects, conservation, cultural heritage protection or forestry as well. In Norway and Greece, it was assumed that the land use and spatial planning legislation would also be liberalised under the Liberalisation scenario, meaning that rural land would be subject to speculation and a strong increase in cabin development (in Norway) and in general tourism infrastructure (in Greece). As to the wilding scenario, stakeholders in general had little understanding of a scenario in which the government spends money on restoring "wild nature" (for example, by re-introducing large predators) while letting rural communities' livelihoods down. Across all study areas most stakeholders were convinced that a well-tended cultural landscape is most attractive for tourists, and that tourism would suffer both in a Liberalisation and a Wilding scenario. In Norway, stakeholders maintained that the accessibility of the landscape would become a problem - also for tourism - if spontaneous reforestation continued. They believed that in the long run, the landscape changes resulting from the Liberalisation and Wilding scenarios would reduce the attractiveness of the area:

I believe many cabin owners will become terribly disappointed within some years when they discover that the cabin that they built in the mountains ends up in the middle of the forest. (Norwegian stakeholder)

Only a minority of stakeholders (mainly in Scotland) argued that the uniqueness of their area lies in its wildness. There was a widespread distrust both of the concept of wilderness and the potential of wilderness tourism:

In this liberalisation scenario we imagine that everything is grown over and the local people are all eaten by bears and wolves. But that's not what they [visitors] want, they want an area that's still alive. (Swiss stakeholder)

Norwegian stakeholders were sceptical about the potential for and benefits to farmers of wilderness tourism, arguing that re-wilding would erode traditional agrotourism and undermine diversification strategies. In Greece, stakeholders regarded their landscape as already "wild enough" and thought that further wilding would inhibit tourism. One aspect of the Liberalisation scenario that was viewed critically in France was the increasing power of agro-industries and supermarket trusts. New food habits (fast food, processed food) and the type of agricultural changes they entail (intensification, 
standardisation) were pointed out. Despite the general rejection of the Liberalisation scenario, there are a few aspects that some stakeholders appreciated. Some farmers would welcome the increase in entrepreneurial freedom in the Liberalisation scenario. They assumed that constraints to diversification in farming would be removed and innovation would be stimulated. In France, a few stakeholders liked the flexibility of the Liberalisation scenario; they thought that liberalisation might bring about some unexpected positive outcomes and new opportunities for farming. Furthermore, they hypothesised that a strong decrease in product prices might force farmers to re-use local resources and to move towards an environment-friendly agriculture. However, many stakeholders disagreed with this assumption, and believed the opposite would become the result of a liberalisation.

Managed Change for Biodiversity received strong support in Greece, and later also in Norway, however after first some very critical comments in the lines of Swiss arguments (see below) stressing that food production has to be at the core of the activities. In Scotland and France, it was rated only slightly lower than the BAU scenario, while in Switzerland and Slovakia the livelihood and cultural rating was slightly negative on average, and significantly lower than the BAU rating. It proved a complex scenario to communicate to stakeholders, however, and some may have misinterpreted it as simply a strengthening of current trends towards the greening of agricultural support. Viewed in these terms, stakeholders who approved the livelihood and cultural aspects of the MCB scenario appear to project onto it an environment-friendly agriculture that takes care of the landscape and offers possibilities for a soft rural tourism, including agro-tourism. In fact, many stakeholders thought that the $\mathrm{MCB}$ scenario would provide favourable general conditions for rural tourism in terms of landscape, biodiversity and cultural heritage. Furthermore in Norway it was assumed that in the MCB scenario new attractive employment opportunities would arise in conservation-related public management.

In Slovakia, the MCB scenario was welcomed by conservation-related stakeholders, but viewed with more scepticism by others. Local farmers trusted more in direct support to agriculture rather than biodiversity conservation. More widespread concerns were related to institutional constraints: the unclear situation regarding land ownership, incoherent and deficient legislation, the gap between different interests, and lack of a leading institution in land management were considered the main barriers for development under a MCB scenario in Slovakia. Similar doubts were expressed by some Greek stakeholders; they pointed to the ineffective management of the existing national park and the unsatisfactory handling of the agricultural subsidy system. For these reasons some Greek stakeholders thought they were not "mature enough" for a MCB scenario.

In Switzerland, stakeholders' criticism of the MCB scenario was of a different nature. There was widespread resistance to a situation in which farmers would only be landscape and biodiversity managers, rather than food producers. Some Swiss stakeholders thought that a biodiversity-optimised agricultural landscape would be artificial, detached from their culture and traditions, although it would look like a traditional landscape and perhaps host a similar diversity of species. It would be a mere nostalgic backdrop in an entirely changed world. Stakeholders believed that visitors are looking for authenticity in mountain regions, and therefore would not appreciate such a landscape. Another important concern among Swiss stakeholders was that they feared a loss of local sovereignty under the MCB scenario, in that farmers would have to adhere to land use prescriptions issued by the authorities. As in France and Scotland some stakeholders expressed concern about a general loss of their local sovereignty under this scenario. To most Swiss and Norwegian stakeholders it would be completely unacceptable if the land was managed by conservation agencies rather than by local farmers. In France and Scotland a few stakeholders were more open to such an idea. However, in several countries stakeholders doubted that conservation agencies would have the skills, knowledge and experience to effectively manage the land for conservation ends: "It's been proved over the years [...] that conservationists can't manage the land for the benefit of biodiversity, quite often they destroy it" (Scottish stakeholder). Only in Slovakia and Greece, stakeholders were less averse to conservation agencies playing an important role as land managers. Many farmers would be willing to adhere to land use prescriptions issued by conservation agencies (e.g. the national park), as long as they are still actively involved in farming and are able to make a living from it. In Slovakia, this may be explained by farmers being used to operate under government management during socialist times (one of the two main farms in the area is still state owned). In the Greek study area, on the other hand, food producing agriculture is already so marginal that farmers are just glad to survive on farms, even if it is primarily as conservation managers.

\subsection{Biodiversity consequences}

It was significant that the biodiversity consequences of the scenarios were less widely debated compared to their possible livelihood consequences.

I don't care about the pipit [Anthus campestris, a bird species present in the French study area]. What I want to see is people down there. I don't want the Causse to be a reserve dedicated to the pipit. If we can live there with the pipit, that's fine. But if we have to choose between the pipit and man, I choose man. (French stakeholder)

In general, stakeholders seemed to care little about the conservation of particular species, although some mentioned certain flowers dear to them. Rather, they perceived and appreciated biodiversity at a habitat or landscape 
Table 2

Stakeholder ratings (mean ratings of each panel) of landscape and livelihoods/socio-cultural consequences

\begin{tabular}{|c|c|c|c|c|c|c|c|c|}
\hline \multirow[t]{2}{*}{ Study area } & \multicolumn{4}{|c|}{ Landscape consequences } & \multicolumn{4}{|c|}{ Livelihoods and socio-cultural consequences } \\
\hline & BAU & LIB & $\mathrm{MCB}$ & WILDING & BAU & LIB & $\mathrm{MCB}$ & WILDING \\
\hline Greece: Zagori & + & - & + & & + & - & - & \\
\hline Slovakia: Poloniny NP & +++ & - & +++ & & +++ & 0 & - & \\
\hline France: Causse Méjan & + & - & +++ & & +++ & -- & +++ & -- \\
\hline Scotland: Cairngorms & + & 0 & ++ & - & ++ & - & ++ & --- \\
\hline Switzerland: Surses & + & - & ++ & & ++ & ---- & - & \\
\hline Norway: East Jotunheimen & - & --- & + & & -- & ---- & ++++ & $*(----)$ \\
\hline
\end{tabular}

Note: Table 2 is based on individual stakeholder ratings of visual and livelihoods/socio-cultural aspects of the scenarios. The original ratings were on a five-point scale. In order to provide a more differentiated picture, the mean ratings of each stakeholder panel were transformed to an eight-point scale. * Stakeholders did not want to rate the Wilding scenario, as they believed it would be a very negative scenario for local livelihoods, thus also with very negative socio-cultural consequences.

---- Mean rating between -1.5 and $-2.0 ;----$ mean rating between -1.0 and -1.5 ; ---- mean rating between -0.5 and $-1.0 ;-$ mean rating between 0 and $-0.5 ; 0$ mean rating $=0 ;+$ mean rating between 0 and $0.5 ;++$ mean rating between 0.5 and $1.0 ;+++$ mean rating between 1.0 and 1.5 ; ++++ mean rating between 1.5 and 2.0 ; blank $=$ not assessed

level - in terms of the diverse flower meadows in Switzerland, the Causse rangelands in France, or the Poloniny meadows in Slovakia, for instance. Often, stakeholders made a clear link between agricultural use and biodiversity. In all study areas, almost all stakeholders saw maintaining biodiversity as an important or even very important function of agriculture in mountain areas. Habitats rich in biodiversity were often seen as landscape elements that essentially build a sense of place and regional identity, not least because they represent traditional forms of land use and thus cultural heritage. Furthermore, many stakeholders in Switzerland and Greece saw a rich biodiversity as a marketing device to attract more visitors. In both study areas, many stakeholders pinned their hopes on protected areas. It can be concluded that local stakeholders see biodiversity conservation not as an aim in itself, but as an anthropocentric project which is wrapped up with the protection of scenic landscapes, traditional agricultural practices, and in some cases with the promotion of rural tourism.

Generally stakeholders believed that the MCB scenario would be best for biodiversity. However, Norwegian and Swiss stakeholders doubted that sufficient funding would be made available. Swiss stakeholders thought that creating and maintaining a small-structured landscape as envisaged in the MCB scenario would be very costly and that a smaller area of land could be supported if funds equivalent to the current amount of agricultural support were invested in biodiversity conservation. They argued that without increased funding more land would be abandoned, which in the end would be detrimental for biodiversity.

Regarding the biodiversity assessment of the BAU scenario, there were marked differences between the countries. In Scotland, Norway and France most stakeholders felt that current trends in agricultural restructuring contribute to the loss of biodiversity. In Norway and France, this perception can probably be explained by the high rate of spontaneous reforestation, while in Scotland it is seen to be due to a reduction in arable land and a trend toward monocultural grass. Slovakian stakeholders were concerned about the current lack of profitability of agriculture and resulting land abandonment, yet they were optimistic that increasing agricultural support from the EU under the BAU scenario would reverse this trend, and thus be beneficial for biodiversity. In Switzerland and Greece, stakeholders were satisfied with the current state of biodiversity in their areas, and they assumed that if current trends continued the level of biodiversity would remain high.

Most stakeholders across the study areas agreed that the Liberalisation scenario would be detrimental for biodiversity, both due to the increased rate of land abandonment and reforestation, and to the intensification of land use on the most productive land. A minority of stakeholders in Scotland believed that the Liberalisation and Wilding scenarios would be beneficial for biodiversity: in the Wilding scenario natural processes would be promoted, and in the Liberalisation scenario the increased need for farmers to be innovative would enhance the structural diversity of land use and thus increase species richness.

Tables 2 and 3 summarise the main findings, that is, stakeholders' assessments of different aspects of the scenarios.

\section{Discussion and conclusions}

Despite the physical, cultural, historical and socioeconomic differences between the study areas, stakeholders assessed the scenarios in remarkably similar ways. They were united in their overall rejection of the Liberalisation scenario and in their significantly more positive assessment of the BAU and MCB scenarios. Furthermore, as a group they put much more weight on the livelihoods and cultural consequences of the scenarios than on their visual and biodiversity consequences. Stakeholders were pessimistic about mountain agriculture's ability to compete in world markets and fearful of the implications of more widespread 
Table 3

Researchers' qualitative estimations of stakeholder biodiversity assessments

\begin{tabular}{|c|c|c|c|c|c|}
\hline \multirow[t]{2}{*}{ Study area } & \multirow[t]{2}{*}{ Biodiversity concept } & \multicolumn{4}{|c|}{$\begin{array}{l}\text { Biodiversity consequences as viewed by the majority of stakeholder } \\
\text { group members }\end{array}$} \\
\hline & & BAU & LIB & $\mathrm{MCB}$ & WILDING \\
\hline Greece: Zagori & $\begin{array}{l}\text { Focused on categories of species related to } \\
\text { stakeholders' lifestyles and interests (e.g. hunting, } \\
\text { shepherding) }\end{array}$ & Neutral & Negative & Positive & Not assessed \\
\hline $\begin{array}{l}\text { Slovakia: } \\
\text { Poloniny NP }\end{array}$ & $\begin{array}{l}\text { Halting of land overgrowing and forest expansion, } \\
\text { lived and farmed landscape, maintenance of extensive } \\
\text { grasslands, especially mountain meadows "poloniny" }\end{array}$ & Positive & Negative & $\begin{array}{l}\text { Ambiguous; } \\
\text { positive if enough } \\
\text { financial support }\end{array}$ & Not assessed \\
\hline $\begin{array}{l}\text { France: Causse } \\
\text { Méjan }\end{array}$ & $\begin{array}{l}\text { Centred on semi-natural rangeland as a major } \\
\text { (quantitatively and culturally) component of } \\
\text { landscape and as a support for sheep farming } \\
\text { (resources for grazing) }\end{array}$ & $\begin{array}{l}\text { Neutral to } \\
\text { Negative }\end{array}$ & Negative & Positive & Negative \\
\hline $\begin{array}{l}\text { Scotland: } \\
\text { Cairngorms }\end{array}$ & $\begin{array}{l}\text { Controversy within the stakeholder group: } \\
\text { "Cultivation of biodiversity through agriculture" } \\
\text { (majority opinion) vs. "biodiversity enhancement } \\
\text { through wilding" (minority opinion) }\end{array}$ & Negative & Negative & Positive & Negative \\
\hline $\begin{array}{l}\text { Switzerland: } \\
\text { Surses }\end{array}$ & $\begin{array}{l}\text { Centred on farmed landscape with open grasslands } \\
\text { used for grazing/hay cut; low intensity flower meadows } \\
\text { as a symbol of high biodiversity }\end{array}$ & Positive & Negative & $\begin{array}{l}\text { Ambiguous; } \\
\text { positive if enough } \\
\text { financial support }\end{array}$ & Not assessed \\
\hline $\begin{array}{l}\text { Norway: East } \\
\text { Jotunheimen }\end{array}$ & $\begin{array}{l}\text { Centred on farmed landscape with open grasslands } \\
\text { used for grazing/hay cut, certain flowers seen as } \\
\text { important as well as some animals }\end{array}$ & Negative & Negative & $\begin{array}{l}\text { Ambiguous; } \\
\text { positive in those } \\
\text { areas qualifying } \\
\text { for support. }\end{array}$ & Not assessed \\
\hline
\end{tabular}

Note: As there was no direct stakeholder rating of the biodiversity consequences of the scenarios, the attributes in table 3 are based on researchers' judgement of stakeholder assessments in the discussions.

liberalisation. Concern that regions will lose their particularity, uniqueness and authenticity was widespread and passionately expressed. This fear was particularly pronounced in the Greek study area, where stakeholders feared tourism-related problems similar to those experienced on the Greek islands, and in Switzerland and Scotland where people talked of the threat of a "disneyfication" of their areas. There was a similar concern in Norway regarding the long term maintenance of cultural heritage, however, with a more positive view on tourism, based on stakeholders' previous experience with small-scale farm tourism. This concern corresponds to an increasing awareness in landscape research of the importance of authenticity as a key concept for the protection of cultural landscape and cultural heritage in general (Daugstad et al., 2006b; Gustavsson and Peterson, 2003; Kianicka et al., 2004, 2006; Pinto-Correia et al., 2006). The majority of stakeholders in all study areas viewed land abandonment and spontaneous reforestation as a consequence of agricultural decline and as a loss of cultural heritage. They saw the cultural heritage in their area as best preserved with a system of active farming, in the sense of a production system based on economic outcomes from producing food and fibre (cf. Daugstad et al., 2006b).

Daugstad et al. (2006b) investigate the connection between agriculture and cultural heritage as expressed by public and private actors who define the policy agenda. They report that the OECD documents examined (OECD, 1999 , 2001) generally conclude that several aspects of agriculture's cultural heritage may be separated from active agriculture, opening up the possibility of establishing 'agricultural parks' in which important landscapes and agricultural structures could be maintained for recreation, experience and cultural heritage. Our evidence from the stakeholder panels, however, points to widespread resistance to such a separation of functions. Most stakeholders believe that the landscape should be primarily managed by local farmers whose primary function should continue to be the production of food and fibre. In their mind, agriculture should continue to play a major role in the provision of biodiversity and landscape services, they regard farmers as the most reliable and skilled custodians of the land, and they question the feasibility of alternative types of landscape management.

Most stakeholders believe that in mountain areas, biodiversity is highest in a cultural landscape, rather than in an untouched wilderness. This can be partly attributed to their greater knowledge of species that inhabit agricultural land compared to those living in wilderness areas. However, they also see with their own eyes that the landscape, with increasing reforestation, is getting more monotonous and visually less diverse, and they infer from this a decline in biodiversity. Similarly, Soini and Aakkula (2007) observed in their recent study of local conceptions of biodiversity in Finland that local people often described the essence and value of biodiversity through aesthetics. Stakeholders are in general aware of the increasing focus on environment-friendly production in agriculture, and they recognise the necessity of agri-environmental schemes and payments, especially in the mountain areas. Many see 
this as a part of their future basis for farming. Although they do not see biodiversity conservation as an end in itself, they are aware of the value of beautiful and well-tended cultural landscapes with a rich biodiversity, as these resources are increasingly sought after by urban residents, and which to some extent may become a basis for farm diversification and rural development. It can thus be summarised that most stakeholders have a pragmatic and utilitarian attitude towards biodiversity conservation, and mainly relate to the wider landscape. Although stakeholders' understanding of biodiversity may be influenced by scientific concepts, there are considerable differences between stakeholders' lay concepts and more 'objective' scientific concepts: stakeholders mainly refer to species and habitats related to agricultural practices or personal interests (e.g. hunting), rather than understanding biodiversity as the variability in natural systems expressed in a range of scales. They usually do not categorise biodiversity in a scientific way, such as distinguishing between native and invasive species, but rather think in categories reflecting their personal interests and lifestyle. Generally, biodiversity is a rather vague and marginal issue for most local stakeholders. Soini and Aakkula (2007) reached a similar conclusion in their in-depth study from Finland.

In several study areas, stakeholders hoped for a higher degree of regional self-sufficiency and a better use of local resources. Some French stakeholders thought that agricultural liberalisation might force farmers to re-use local resources and to move towards an environment-friendly agriculture. Norwegian stakeholders went further in anticipating a global environmental crisis that would force higher levels of self-sufficiency based on low-intensive environmentally friendly farming methods. They developed their own 'Environment and Solidarity' scenario, which embodies an extreme version of a vision common to many study areas: stakeholders dream of a world in which local farmers, both at home as well as in developing countries, cultivate all or most of the productive land in an environment-friendly way, for which they are shown respect and solidarity by the public. Norwegian stakeholders saw a global energy, environmental and food crisis as the only way out of a situation in which the South and the environment are systematically and increasingly exploited, and in which much of their fates are decided upon in WTO negotiations and in the offices of transnational companies. In other words: if globalisation and liberalisation are progressing and solidarity is dwindling, only a global crisis can reverse this trend!

The questionnaire results clearly showed that stakeholders ascribe several functions to mountain agricultureincluding agricultural production, but with the production of staple food scoring lowest. It thus appears that stakeholders in the study areas support the notion of a multifunctional agriculture. The importance of pluriactivity and part-time farming must also be stressed, and a major argument from many stakeholders was that farm income cannot be fully replaced by other types of income. Our results indicate that most farmers in the study areas are production-oriented, although often not productivist in the sense described by Lowe et al. (1993). They still see agricultural production as the basis of mountain agriculture, and landscape and biodiversity conservation in the cultural landscape mostly as a by-product of environmentally sound farming practices. However, by agricultural production they mean, above all, the production of quality regional specialities, organic food and other niche products, rather than staple foods.

It has been observed in the present study that visual landscape assessments cannot be fully separated from nonvisual aspects. This appears to be particularly true if the photo visualisations are assessed by local residents, who live and work in the region, who use and manage the land, and who may have their personal 'stories' to tell regarding these locations. If the respondents did not have any personal connection to the region and the visualised sites, their assessment of the photo simulations probably would have been more focused on the visual dimension, and less influenced by socio-economic and cultural aspects. The findings of Gehring (2006) support this assumption: in their study of landscape preferences in the Swiss Alps, economic considerations seemed to influence Alpine residents' judgements of landscape visualisations more than those of other Swiss residents. Similarly, Coeterier (1996) concludes from his study of landscape perceptions of local residents in the Netherlands that use aspects are particularly important to residents, and that to them, landscape functions such as the provision of a sense of security, of freedom, of privacy, or of possibilities for action are more important than pictorial attributes. From a psychological perspective, Fuhrer et al. (1993) showed that the three factors directing social actions and that seem to influence landscape preferences - security, arousal and personal autonomy - are related to people's attachment to their home and near-home territories. Furthermore, several studies show that landscape preferences may differ across social and demographic groups (e.g. Gonzalez-Bernaldez and Parra, 1979; van den Berg et al., 1998), between experts and lay-persons (e.g. Kaplan, 1988) and that living environment (urban versus rural), education level, and occupational interests influence landscape preferences ( $\mathrm{Yu}$, 1995). This may explain why the results of our study are rather incongruent with the notion that people tend to prefer landscapes with a medium degree of forestation, which was theoretically developed by environmental psychologists (e.g. Purcell, 1987; Kaplan et al., 1989; Bourassa, 1991) and empirically confirmed in the Swiss Alps by Hunziker (1995) and Hunziker and Kienast (1999) with samples of Alpine residents and visitors, and university students. Most stakeholders in all the study areas associated landscape visualisations showing spontaneous reforestation with agricultural decline and implied wider negative consequences on the communities, and hence rated them negatively. 
It is not surprising that most of the stakeholders visually prefer landscapes that resemble the 'traditional' agricultural landscapes of the past, as embodied in the MCB scenario. Similar findings are reported from other landscape preference studies (see, e.g. Strumse, 1996; Daugstad et al., 2002 for Norway; Højring and Caspersen, 1999; Tress and Tress, 2003a for Denmark; O'Riordan et al., 1990 for UK). This can be partly explained by aesthetic theory (Nohl, 2001), but also by what may be referred to as 'nostalgia'; the small-structured landscapes may remind rural stakeholders of the 'good old days' when agriculture was less industrialised and less dependent on outside resources and financial support linked to provisions directed centrally, when the public appreciated farmers' work more and when social contact among farmers and in village communities was stronger. Hunziker (2000), referring to Hoisl et al. (1987), remarks that lay-persons tend to prefer "traditional" cultural landscapes because in a time of rapid societal change, they associate them with a "better society', with which they still identify. On the other hand, the stakeholders appreciate technological progress and improvements in standards of living. A similar ambiguity can be observed in the Norwegian 'Environment and Solidarity' scenario. Initially, stakeholders longed for a future in which, like in the past, most of the farm land is utilised for food production, and in an environmentfriendly way with little input factors, in which better use is made of local resources, and farmers are treated with respect due to their important role as food providers. But on further reflection they preferred the $\mathrm{MCB}$ to the Environment and Solidarity scenario because the latter could, under the changed conditions, lead to social tensions and to a forced concentration of farmers' activities on agricultural production. They appreciated the diversity, openness and mobility that an increasingly post-productivist rural society actually may offer. They saw agrotourism as a possibility of meeting people from distant places, and therefore as an enrichment of their lives.

There are a number of factors accounting for the (remarkably small) differences in stakeholder assessments between the study areas. Firstly, the level of land abandonment and forest regrowth and the degree to which these processes are perceived as threats vary between the study areas. While in Scotland, for instance, forest recolonisation was attributed partly as a positive natural process, it was seen as a major biodiversity threat in Norway. Secondly, there are differences in land ownership structure, as well as historical continuities or discontinuities in land use, that influence stakeholder assessments. A third explanation relates to differences in past and present agricultural policies and the resulting agricultural structure and restructuring, as well as varying expectations of future agricultural policies. In this regard, the study areas can be roughly divided into three groups: old EU members (UK, France, Greece), new EU members (Slovakia), and non-EU-members (Norway, Switzerland). While in Norway and Switzerland with their highly protected agricultural markets, agricultural stakeholders have most to lose in the case of agricultural liberalisation, stakeholders in Slovakia, the poorest study area, are confident that they will benefit from EU support even if agriculture is slightly more liberalised in the future. Old EU member states are between these extremes. Fourthly, prospects for agricultural diversification and pluriactivity vary between the study areas. Linked to this is the perception of tourism - a major potential source of income for many stakeholders - as a possibility for maintaining or threatening landscapes and cultural heritage. The degree of tourism development also influence stakeholders' attitudes: while the Greek stakeholders referred to negative experiences with (mass) tourism, Norwegian stakeholders referred to personal, positive experience from mainly smallscale farm based tourism. Finally, variations in stakeholder group composition and in the dominant discourses contribute to differences in viewpoints.

Generally, most stakeholders are in favour of nature conservation, as implemented through agri-environmental schemes and protected areas, if they are directly involved and derive a benefit, and perhaps most importantly, if these measures allow the continuation of some type of farming in the area. In several study areas, stakeholders hope that protected areas will further stimulate rural tourism. However, an entirely different picture emerges if protected areas are established primarily for the protection or restoration of natural processes and "wild nature". While urban citizens increasingly seek what they see as "wild" areas for recovery as a contrast to urban life, rural stakeholders reject a 're-wilding' of their areas. They are also sceptical regarding the potential of wilderness tourism. There is evidence from recent studies pointing to a gap between rural and urban points of view regarding natural reforestation and the restoration of wilderness (Hunziker, 2000; O'Rourke, 2000; Hunziker et al., 2001; Bauer, 2005; Buijs et al., 2006; Gehring, 2006). While there is an increasing demand for wild nature, there is also a seeking for 'intact' cultural landscapes and the heritage they represent (Daugstad et al., 2005, 2006a). According to Daugstad et al. (2006b), physical cultural heritage such as buildings, pastures and hedgerows are increasingly valued for their ability to provide a feeling of identity, rootedness and mental restoration. This implies that mountain agriculture should not only be defended because it supplies environmental goods and tourism services, but also because it is a 'provider of identity'.

The degree to which those who manage land succeed in maintaining an attractive visual environment in Europe's mountain areas will be a factor in the long term economic sustainability of these areas. A positive future development in Europe's mountain areas is going to depend on its attractive environment. The scenario analysis presented here suggests that biodiversity, landscape and cultural qualities cannot realistically be upheld without some type of state support. If wider society is to be provided with these environmental and cultural goods of the mountain 
landscapes, the nature of government support for upland agriculture will need to continue its evolution towards a more decoupled, environmentally orientated system. Based on the experience of this Europe-wide comparative study, the conclusion is that there is a need for a combination of payments, maintaining wider landscape qualities through continued, low-intensive, farming methods, and more specific measures targeting especially valuable or important biodiversity and cultural heritage aspects. These need to be seen together with efforts for new business developments and on and off-farm diversification; state subsidies for natural and cultural heritage conservation and management must also be seen to be linked to private investments as well as public schemes for rural development. The future legitimacy of such schemes is a major issue.

In spite of the many landscape preference studies that have been conducted, there is still a need for better informed dialogues between rural and urban $^{2}$ citizens regarding the future of mountain areas. It could be fruitful to conduct the same research with urban residents, i.e. with potential visitors to mountain areas. Urban areas are the places where most voters and tax payers live and where many decisions with far-reaching consequences are taken. Mutual understanding may be promoted by bringing together different stakeholders from rural and urban areas. The BioScene project has shown that stakeholder meetings can be a useful way to gain an understanding of stakeholder views and to initiate a debate. The views, needs and perceived and actual threats of the various stakeholders must be understood and properly communicated in order to realise the potential for transition of European mountain areas from 'less-favoured' agricultural landscapes to 'highly-valued' environmental landscapes.

\section{Acknowledgements}

BioScene (Scenarios for reconciling biodiversity conservation with declining agricultural use in the mountains of Europe-project number EVK2-2001-00354) was funded under the EU 5th Framework Energy, Environment and Sustainable Development, supported by the European Commission.

\section{References}

Al-Kodmany, K., 1999. Using visualization techniques for enhancing public participation in planning and design: process, implementation, and evaluation. Landscape and Urban Planning 45, 37-45.

Barbanente, A., Khakee, A., Puglisi, M., 2002. Scenario building for Metropolitan Tunis. Futures 34, 583-596.

Bätzing, W., 2003. Die Alpen. Geschichte und Zukunft einer europäischen Kulturlandschaft. CH Beck, München.

Bauer, N., 2005. Für und wider Wildnis. Soziale Dimensionen einer aktuellen gesellschaftlichen Debatte. Haupt, Bern.

\footnotetext{
${ }^{2}$ 'Urban' and 'rural' is here simplified to be understood as dichotomies, however, 'urban' groups or citizens holding 'urban views' may also be found within rural communities.
}

Bezák, P., Petrovic, F., 2006. Agriculture, landscape, biodiversity: scenarios and stakeholder perceptions in the Poloniny National Park (NE Slovakia). Ekológia (Bratislava) 25, 82-93.

Bolliger, J., Kienast, F., Soliva, R., Rutherford, G., in press. Spatial sensitivity of species habitat patterns to scenarios of land use change (Switzerland). Landscape Ecology.

Bourassa, S.C., 1991. The Aesthetics of Landscape. Belhaven Press, London/New York.

Buijs, A.E., Pedroli, B., Luginbühl, Y., 2006. From hiking through farmland to farming in a leisure landscape: changing social perceptions of the European landscape. Landscape Ecology 21, 375-389.

Busch, G., 2006. Future European agricultural landscapes - what can we learn from existing quantitative land use scenario studies? Agriculture, Ecosystems \& Environment 114, 121-140.

Caplat, P., Lepart, J., Marty, P., submitted. Modelling the effects of land use and dispersal on Pinus sylvestris dynamics in a Mediterranean upland. Basic and Applied Ecology.

CBD, 1992. Convention on Biological Diversity. Available online at < http://www.biodiv.org/convention/articles.asp $>$. Last accessed 3 July 2006.

Coeterier, J.F., 1996. Dominant attributes in the perception and evaluation of the Dutch landscape. Landscape and Urban Planning $34,27-44$.

Cooke, B., Kothari, U. (Eds.), 2001. Participation: The New Tyranny? Zed Books, London.

Daugstad, K., Ringdal, S., Rønningen, K., Skar, B., 2002. Agriculture and Cultural Heritage. A state of the Art Report on Research Based Knowledge. R-7/02. Centre for Rural Research, Trondheim.

Daugstad, K., Svarstad, H., Vistad, O.I., 2005. Local participation in nature protection: magic or mistake? In: Heberlein, T., Fredman, P. (Eds.), ISSRM 2005, the 11th International Symposium on Society and Resource Management. June 16-19 2005 Östersund, Sweden. Book of Abstracts. ISSRM, Östersund, Sweden, p. 110.

Daugstad, K., Svarstad, H., Vistad, O.I., 2006a. A case of conflicts in conservation: two trenches or a three-dimensional complexity? Landscape Research 31, 1-19.

Daugstad, K., Rønningen, K., Skar, B., 2006b. Agriculture as an upholder of cultural heritage? Conceptualizations and value judgements - a Norwegian perspective in international context. Journal of Rural Studies 22, 67-81.

Dodgshon, R.A., Olsson, G.A., 2007. Seasonality in European mountain areas: a study in human ecology. In: Palang, H., Sooväli, H., Printsmann, A. (Eds.), Seasonal Landscapes, Landscape Series, vol. 7. Springer, Dordrecht, pp. 85-101.

Ewert, F., Rounsevell, M.D.A., Reginster, I., Metzger, M.J., Leemans, R., 2005. Future scenarios of European agricultural land use: I. Estimating changes in crop productivity. Agriculture, Ecosystems \& Environment 107, 101-116.

Fraser, E.D.G., Dougill, A.J., Mabee, W.E., Reed, M., McAlpine, P., 2006. Bottom up and top down: analysis of participatory processes for sustainability indicator identification as a pathway to community empowerment and sustainable environmental management. Journal of Environmental Management 78, 114-127.

Fuhrer, U., Kaiser, F., Hartig, T., 1993. Place attachment and mobility during leisure time. Journal of Environmental Psychology 13, 309-321.

Gehring, K., 2006. Landscape Needs and Notions. Preferences, expectations, leisure motivation, and the concept of landscape from a crosscultural perspective. Swiss Federal Research Institute WSL, Birmensdorf.

Gonzalez-Bernaldez, F., Parra, F., 1979. Dimensions of landscape preferences from pairwise comparisons. In: Elsner, G.H., Smardon, R.D. (Eds.), Our National Landscape. A Conference on Applied Techniques for Analysis and Management of the Visual Resource. General Technical Report PSW-35, USDA Forest Service, Berkeley, CA, USA, pp. 256-262.

Goodman, D., 2004. Rural Europe Redux? Reflections on alternative agro-food networks and paradigm change. Sociologia Ruralis 44, $3-16$. 
Gustavsson, R., Peterson, A., 2003. Authenticity in landscape conservation and management - the importance of the local context. In: Palang, H., Fry, G. (Eds.), Landscape Interfaces. Landscape Series, vol. 1. Kluwer Academic Publishers, Dordrecht/Boston/London, pp. 319-356.

Haddock, J., Tzanopoulos, J., Mitchley, J., Fraser, R., 2007. A method for evaluating alternative landscape management scenarios in relation to the biodiversity conservation of habitats. Ecological Economics 61, 277-283.

Halabuk, A., Halada, L., 2006. Modelling of grassland distribution in the Poloniny National Park. Ekológia 25, 138-150.

Hoisl, R., Nohl, W., Zekorn, S., Zöllner, G., 1987. Landschaftsästhetik in der Flurbereinigung. Empirische Grundlagen zum Erlebnis der Agrarlandschaft. Materialien zur Flurbereiningung, Heft 11. Bayrisches Staatsministerium für Ernährung, Landwirtschaft und Forsten, München.

Højring, K., Caspersen, O.H., 1999. Landbrug og landskabsæstetikUdviklingen af landbruget 150-1995 og dens konsekvenser for landskabets oplevelsesesmæssige indhold. Park og landskabsserien no 25. Forskningscenteret for Skov og Landskab, Denmark.

Höll, A., Andersen, E., Rygnestad, H., Dalgaard, T., Johansson, T.D., Sørensen, E.M., Nilsson, K., 2002. Scenario analyses for cultural landscape development - a Danish, interdisciplinary research project. Geografisk Tidsskrift 3, 1-12.

Hunziker, M., 1995. The spontaneous reafforestation in abandoned agricultural lands: perception and aesthetic assessment by locals and tourists. Landscape and Urban Planning 31, 399-410.

Hunziker, M., 2000. Einstellungen der Bevölkerung zu möglichen Landschaftsentwicklungen in den Alpen. Eidgenössische Forschungsanstalt WSL, Birmensdorf, Switzerland.

Hunziker, M., Kienast, F., 1999. Potential impacts of changing agricultural activities on scenic beauty - a prototypical technique for automated rapid assessment. Landscape Ecology 14, 161-176.

Hunziker, M., Hoffmann, C., Wild, S., 2001. Die Akzeptanz von Raubtieren, Gründe und Hintergründe - Ergebnisse einer repräsentativen Umfrage in der Schweiz. Forest, Snow and Landscape Research 76, 301-326.

Jodha, N.S., 1997. Mountain agriculture. In: Messerli, B., Ives, J.D. (Eds.), Mountains of the World. A Global Priority. The Parthenon Publishing Group, New York/London, pp. 313-335.

Kaplan, S., 1988. Perception and landscape: conceptions and misconceptions. In: Nasar, J.L. (Ed.), Environmental Aesthetics: Theory, Research, and Applications. Cambridge University Press, Cambridge, pp. $45-55$.

Kaplan, R., Kaplan, S., Brown, T., 1989. Environmental preference-a comparison of four domains of predictors. Environment and Behavior 21, 509-530.

Kianicka, S., Gehring, K., Buchecker, M., Hunziker, M., 2004. Wie authentisch ist die Schweizer Alpenlandschaft für uns? Bündner Monatsblatt 2, 196-210.

Kianicka, S., Buchecker, M., Hunziker, M., Müller-Böker, U., 2006. Locals' and Tourists' Sense of Place. A case Study of a Swiss Alpine village. Mountain Research and Development 26, 55-63.

Lowe, P., Murdoch, J., Marsden, T., Munton, R., Flynn, A., 1993. Regulating the new rural spaces: the uneven development of land. Journal of Rural Studies 9, 205-222.

Marsden, T., Murdoch, J., Morgan, K. (Eds.), 1999. Sustainable agriculture, food supply chains and regional development: editorial introduction, International Planning Studies 4, 295-301.

Marty, P., 2005. Activités humaines et production des espaces naturels. In: Marty, P., Vivien, F.-D., Lepart, J., Larrère, R. (Eds.), Les biodiversities: Objets, Theories, Pratiques. CNRS Editions, Paris, pp. 195-208.

Miele, M., Murdoch, J., 2003. Fast food/slow food: standardizing and differentiating cultures of food. In: Almås, R., Lawrence, G. (Eds.), Globalization, Localization and Sustainable Livelihoods. Ashgate, Basingstoke, pp. 25-42.
Münier, B., Birr-Pedersen, K., Schou, J.S., 2004. Combined ecological and economic modelling in agricultural land use scenarios. Ecological Modelling 174, 5-18.

Nohl, W., 2001. Landschaftsplanung. Ästhetische und rekreative Aspekte. Patzer, Berlin/Hannover.

OECD, 1999. Cultivating rural amenities. An economic development perspective. OECD, Paris.

OECD, 2001. Multifunctionality. Towards an Analytical Framerwork. OECD, Paris.

Olsson, G.A., Hanssen, S.K., Rønningen, K., 2004. Different conservation values of biological diversity? A case study from the Jotunheimen mountain range, Norway. Norsk Geografisk Tidsskrift-Norwegian Journal of Geography 58, 1-9.

Olsson, G.A., Rønningen, K., Hanssen, S.K., Wehn, S., submitted. The interrelationship of biodiversity and rural viability in mountain environments - a sustainability assessment of land use scenarios. Landscape and Urban Planning.

O'Riordan, T., Wood, T.C., Shadrake, A., 1990. Interpreting landscape futures. In: Kulhavy, D., Hegg, L., Michael, H. (Eds.), What's Past is Prologue. Our Legacy - Our Future. Austin State University, Austin, TX, pp. 341-349.

O'Rourke, E., 2000. The reintroduction and reinterpretation of the wild. Journal of Agricultural and Environmental Ethics 13, 45-165.

Orland, B., Budthimedhee, K., Uusitalo, J., 2001. Considering virtual worlds as representations of landscape realities and as tools for landscape planning. Landscape and Urban Planning 54, 139-148.

Palang, H., Alumäe, H., Mander, Ü., 2000. Holistic aspects in landscape development: a scenario approach. Landscape and Urban Planning 50, 85-94.

Parish, R., 2002. Mountain Environments. Prentice-Hall, Harlow, England.

Pedroli, B., Pinto-Correia, T., Cornish, P., 2006. Landscape-what's in it? Trends in European landscape science and priority themes for concerted research. Landscape Ecology 21, 421-430.

Penker, M., Wytrzens, H.K., 2005. Scenarios for the Austrian food chain in 2020 and its landscape impacts. Landscape and Urban Planning 71, 175-189.

Pinto-Correia, T., Gustavsson, R., Pirnat, J., 2006. Bridging the gap between centrally defined policies and local decisions - towards more sensitive and creative rural landscape management. Landscape Ecology 21, 333-346.

Purcell, A.T., 1987. Landscape perception, preference and schema discrepancy. Environment and Planning B: Planning and Design 14, $67-92$.

Rønningen, K., 1999. Agricultural policies and countryside management - a comparative European study. Doctoral Thesis. Norwegian University of Science and Technology, Department of Geography, Trondheim, Norway.

Rounsvell, M.D.A., Reginster, I., Araújo, M.B., Carter, T.R., Dendoncker, N., Ewert, F., House, J.I., Kankaanpää, S., Leemans, R., Metzger, M.J., Schmit, C., Smith, P., Tuck, G., 2006. A coherent set of future land use change scenarios for Europe. Agriculture, Ecosystems \& Environment 114, 57-68.

Scholz, R.W., Stauffacher, M., Bösch, S., Wiek, A. (Eds.), 2002. Landschaftsnutzung für die Zukunft-Der Fall Appenzell Ausserrhoden. ETH-UNS Case Study 2001. Rüegger/Pabst, Zürich.

Shearer, A.W., 2005. Approaching scenario-based studies: three perceptions about the future and considerations for landscape planning. Environmental Planning B 32, 67-87.

Søderkvist Kristensen, L., Thenail, C., Kristensen, S.P., 2004. Landscape changes in agrarian landscapes in the 1990s: the interaction between farmers and the farmed landscape. A case study from Jutland. Denmark. Journal of Environmental Management 71, 231-244.

Soini, K., Aakkula, J., 2007. Framing the biodiversity of agricultural landscape: the essence of local conceptions and constructions. Land Use Policy 24, 311-321.

Soliva, R., 2007. Landscape stories: using ideal type narratives as a heuristic device in rural studies. Journal of Rural Studies 23, 62-74. 
Soliva, R., Hunziker, M., submitted. Beyond the visual dimension: using ideal-type narratives to analyze people's assessments of landscape scenarios. Land Use Policy.

Strumse, E., 1996. The psychology of aesthetics. Explaining visual preferences for agrarian landscapes in Western Norway. Doctoral Thesis in Psychology. University of Bergen, Norway.

Svarstad, H., Daugstad, K., Vistad, O.I., Guldvik, I., 2006. New protected areas in Norway: local participation without women. Mountain Research and Development 26, 48-54.

Swiss Federal Council, 2007. Stellungnahme des Bundesrates vom 28.02.2007 zur Motion. Förderung der inländischen Nahrungsmittelproduktion. Available online at $\langle\mathrm{http}: / /$ search.parlament.ch/cvgeschaefte?gesch_id $=20063880\rangle$. Last accessed 22 March 2007.

Tellstrom, R., Gustafsson, I.B., Mossberg, L., 2005. Local food cultures in the Swedish rural economy. Sociologia Ruralis 45, 346-359.

Tress, B., Tress, G., 2003a. Scenario visualization for participatory landscape planning - a study from Denmark. Landscape and Urban Planning 64, 161-178.

Tress, B., Tress, G., 2003b. Communicating landscape development plans through scenario vizualisation techniques. In: Palang, H., Fry, G. (Eds.), Landscape Interfaces. Cultural Heritage in Changing Landscapes, Landscape Series. Kluwer Academic Publishers, Dordrecht/ Boston/London, pp. 185-220.

Twyman, C., 2000. Participatory conservation? Community-based natural resource management in Botswana. The Geographical Journal 166, $323-335$. van den Berg, A.E., Vlek, C.A.J., Coeterier, J.F., 1998. Group differences in the aesthetic evaluation of nature development plans: a multilevel approach. Journal of Environmental Psychology 18, 141-157.

van der Ploeg, J.D., Renting, H., 2000. Impact and potential: a comparative review of European development practices. Sociologia Ruralis 40, 529-543.

van der Ploeg, J.D., Renting, H., 2004. Behind the 'Redux': a rejoinder to David Goodman. Sociologia Ruralis 44, 233-242.

van Meijl, H., van Rheenen, T., Tabeau, A., Eickhout, B., 2006. The impact of different policy environments on agricultural land use in Europe. Agriculture, Ecosystems \& Environment 114, 21-38.

Veeneklaas, F.R., van den Berg, L.M., 1995. Scenario building: art craft or just a fashionable whim? In: Schoute, J.F.Th., Finke, P.A., Veeneklaas, F.R., Wolfert, H.P. (Eds.), Scenario Studies for the Rural Environment. Kluwer Academic Publishers, Dordrecht/Boston/London, pp. 11-13.

Verburg, P.H., Schulp, C.J.E., Witte, N., Veldkamp, A., 2006. Downscaling of land use change scenarios to assess the dynamics of European landscapes. Agriculture, Ecosystems \& Environment 114, $39-56$.

Westhoek, H.J., van den Berg, M., Bakkes, J.A., 2006. Scenario development to explore the future of Europe's rural areas. Agriculture, Ecosystems \& Environment 114, 7-20.

Yu, K., 1995. Cultural variations in landscape preference: comparisons among Chinese sub-groups and Western design experts. Landscape and Urban Planning 32, 107-126. 